\title{
Prediksi Harga Bahan Pokok Nasional Jangka Pendek Menggunakan ARIMA
}

\author{
Mohammad Arif Rasyidi \\ Departemen Informatika, Universitas Internasional Semen Indonesia \\ Jalan Veteran, Gresik \\ mohammad.rasyidi@uisi.ac.id
}

\begin{abstract}
Abstrak - Fluktuasi harga bahan pokok yang tidak terkendali dapat menyebabkan kerugian bagi konsumen maupun produsen. Salah satu langkah untuk mengatasi permasalahan tersebut yaitu dengan membuat prediksi harga yang akurat sehingga tindakan preventif dapat dilakukan untuk meminimalkan gejolak harga. Dalam studi ini, ARIMA digunakan untuk memprediksi harga bahan pokok nasional dalam jangka pendek. Data harga harian dari dua belas bahan pokok pada empat horizon prediksi (1 hingga 30 hari ke depan) digunakan untuk menguji kinerja ARIMA dalam memprediksi harga bahan pokok. Hasil eksperimen menujukkan bahwa model ARIMA yang dihasilkan mampu memprediksi harga dengan tingkat error ratarata sebesar $2.22 \%$.
\end{abstract}

Kata Kunci-ARIMA, Bahan Pokok, Prediksi, Peramalan

Abstract - Uncontrolled price fluctuation of basic commodities can harm both consumers and producers. One way to overcome the problem is by making accurate price prediction so that preventive actions can be conducted to minimize the price fluctuation. In this study, ARIMA is used to make short-term price prediction of national basic commodities. Daily pricing data of twelve commodities in four prediction horizons (1 to 30 days ahead) is used to test the performance of ARIMA in predicting the commodity prices. The experimental results showed that the ARIMA model was able to predict the price quite accurately with an average error rate of $2.22 \%$.

Keywords- ARIMA, Basic Commodities, Forecast, Prediction

Article history:

Received 25 August 2017; Received in revised form 22 September 2017; Accepted 4 October 2017;

Available online 28 October 2017

\section{PENDAHULUAN}

Terpenuhinya kebutuhan akan bahan pokok merupakan salah satu hal yang penting dalam kehidupan. Hanya saja, ketidak stabilan harga membuat kebutuhan ini menjadi sulit terpenuhi. Pada umumnya, harga terbentuk karena adanya interaksi antara penawaran dan permintaan. Jika penawaran tinggi dan permintaan rendah, maka harga akan turun. Sebaliknya, jika penawaran rendah sedangkan permintaan tinggi, maka harga akan naik. Hal ini sedikit berbeda dengan bahan pokok, terutama untuk produk pertanian. Karena sifatnya yang sangat penting bagi kehidupan, permintaan akan bahan pokok cenderung stabil (inelastis) terhadap perubahan harga (Firdaus, 2012). Hal inilah yang menyebabkan harga bahan pokok menjadi sangat fluktuatif saat terjadi perubahan penawaran.

Studi ini bertujuan untuk memprediksi harga bahan pokok nasional dalam jangka pendek (1 hingga 30 hari ke depan). Dengan adanya prediksi harga yang akurat, maka pemerintah dapat menjamin harga bahan pokok tetap terjangkau oleh konsumen melalui mekanisme operasi pasar saat harga diprediksi naik secara drastis. Di sisi lain, prediksi yang akurat dapat menjadi acuan bagi produsen, baik petani maupun peternak, dalam menjual produknya ke pemasok maupun konsumen akhir.

Pada penelitian sebelumnya, (Ditakristy, Saepuddin, \& Nhita, 2016), (Nanggala, Saepuddin, \& Nhita, 2016), dan (Widyadarma, Saepuddin, \& Nhita, 2016) memprediksi harga mingguan bawang merah dan cabai merah biasa menggunakan radial basis function neural network (RBFNN), Elman Recurrent Neural Network (ERNN), dan kombinasi neural network dan algoritma genetika. Namun, akurasi yang didapatkan masih cukup rendah, sekitar $\pm 75 \%$.

Pada studi ini, ARIMA digunakan untuk memprediksi harga harian 12 bahan pokok dalam jangka pendek antara 1 hingga 30 hari ke depan. (Sen, Roy, \& Pal, 2016) menyatakan bahwa ARIMA cocok untuk digunakan dalam peramalan time series jangka pendek. Metode ini juga telah banyak diterapkan untuk peramalan dalam berbagai bidang. (Hikichi, Salgado, \& \& Beijo, 2017) misalnya, menerapkan ARIMA untuk memprediksi banyaknya sertifikasi ISO $14001 \mathrm{di}$ Amerika utara, (Goyal, Chan, \& Jaiswal, 2006) dan (Liu, 2009) menggunakannya untuk memprediksi polusi di lingkungan perkotaan, (Ediger \& Akar, 2007) memanfaatkannya untuk memprediksi kebutuhan energi berdasarkan jenisnya, sedangkan (Mohamed \& Bodger, 2005) 
memprediksi konsumsi listrik berdasarkan variabel ekonomi dan demografi.

\section{MetOde PENELITIAN}

Prediksi harga bahan pokok dapat dilihat sebagai sebuah permasalahan peramalan time series. Misalkan $t$ melambangkan waktu saat ini, maka time series $\mathbf{y}(t)=\left(x_{1}, x_{2}, x_{3}, \ldots, x_{t}\right)$ merupakan sebuah deret dari observasi (harga bahan pokok) yang diukur dalam interval waktu yang sama hingga $t$. Peramalan time series dengan demikian dapat didefinisikan sebagai sebuah permasalahan untuk memprediksi $h$ nilai berurutan di masa depan: $\mathbf{y}_{t}(h)=\left(x_{t+1}, x_{t+2}, x_{t+3}, \ldots, x_{t+h}\right)$ dengan menggunakan sebagian atau seluruh observasi yang ada di $\mathbf{y}$ dan juga observasi-observasi lain jika diperlukan. Disini $h$ merupakan horizon prediksi (prediction horizon), yang menentukan seberapa jauh di masa depan nilai yang ingin diramalkan.

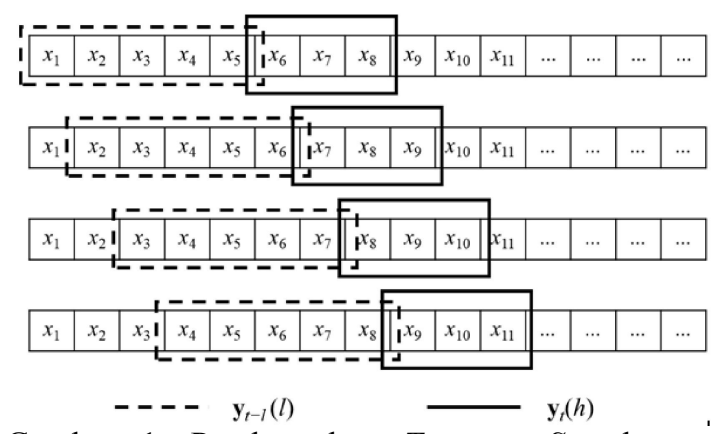

Gambar 1. Pembentukan Training Set dengan Sliding Window Berukuran 5 dan Prediction Horizon 3

Pada umumnya, nilai yang akan datang berkorelasi dengan beberapa nilai terbaru. Dengan demikian, untuk meramalkan $\mathbf{y}_{t}(h)$ seringkali tidak semua nilai yang ada di $\mathbf{y}$ perlu untuk digunakan. Training set untuk membentuk model prediksi dibangun dengan cara menyusun time series yang ada menjadi vektor-vektor berukuran $l$ dengan cara menggesernya satu per satu (sliding window) seperti diilustrasikan pada Gambar 1. Vektorvektor dalam bentuk $\mathbf{y}_{t-l}(l)=\left(x_{t-l+1}, x_{t-l+2}, x_{t-l+3}\right.$, $\left.\ldots, x_{t}\right)$ ini sering disebut sebagai lag vector, sedangkan $l$ disebut sebagai window size yang menentukan banyaknya observasi yang digunakan untuk meramalkan nilai yang akan datang, yaitu $\mathbf{y}_{t}(h)$. Dengan demikian, permasalahan pada kasus ini adalah mencari fungsi $f$ yang memetakan $\mathbf{y}_{t-l}(l)$ ke nilai yang akan datang $\mathbf{y}_{t}(h)$ seakurat mungkin:

$$
f^{*}=\underset{f}{\arg \min } \sum_{\left(\mathbf{y}_{t-l}(l), \mathbf{y}_{t}(h)\right) \in E} L\left(\mathbf{y}_{t}(h), f\left(\mathbf{y}_{t-l}(l)\right)\right)
$$

dimana $L$ merupakan fungsi loss dan $E$ adalah training set.
Penelitian ini mengimplementasikan model ARIMA untuk memprediksi harga bahan pokok nasional. Model $\operatorname{ARIMA}(p, d, q)$ terdiri dari tiga bagian: AR (autoregression, order $p$ ), MA (moving average, $\operatorname{order} q$ ), dan jumlah diferensiasi (integrasi) yang dilakukan (order $d$ ). Diferensiasi merupakan transformasi yang dilakukan untuk menjadikan data tersebut stasioner. Untuk mendiferensiasi data, selisih dari observasi yang berurutan dihitung secara matematis untuk membentuk time series baru dengan rumus:

$$
x_{t}^{\prime}=x_{t}-x_{t-1}
$$

Jika data masih belum stasioner, diferensiasi lanjutan dapat dilakukan dengan mendiferensiasi hasil sebelumnya. Misalnya untuk diferensiasi order 2 dapat dihitung sebagai berikut:

$$
\begin{aligned}
x_{t}^{\prime \prime} & =x_{t}^{\prime}-x_{t-1}^{\prime} \\
& =\left(x_{t}-x_{t-1}\right)-\left(x_{t-1}-x_{t-2}\right) \\
& =x_{t}-2 x_{t-1}+x_{t-2}
\end{aligned}
$$

Setelah data time series diubah ke dalam bentuk stasioner, nilai yang akan datang kemudian dapat diprediksi dengan menggunakan rumus:

$$
\begin{aligned}
\hat{x}_{t}= & \delta+\varphi_{1} x_{t-1}+\varphi_{2} x_{t-2}+\cdots+\varphi_{p} x_{t-p} \\
& +\varepsilon_{t}-\theta_{1} \varepsilon_{t-2}-\theta_{1} \varepsilon_{t-2}-\cdots-\theta_{q} \varepsilon_{t-q}
\end{aligned}
$$

dimana $\delta$ adalah konstanta, $\varphi_{1}, \varphi_{2}, \ldots, \varphi_{p}$ adalah parameter autoregressive, $\varepsilon_{t}$ adalah nilai acak pada waktu $t$ dengan sebaran $N\left(0, \sigma^{2}\right)$ dan $\theta_{1}, \theta_{2}, \ldots, \theta_{q}$ adalah parameter moving average. Model ARIMA dapat dibangun dengan tiga tahapan yaitu identifikasi, estimasi parameter, dan pemeriksaan diagnotik.

1) Identifikasi: Pada tahapan ini, order $\mathrm{p}$, d, dan q dari ARIMA. Banyaknya diferensiasi yang dibutuhkan (d) ditentukan dengan menggunakan ACF (auto correlation function), PACF (partial $\mathrm{ACF}$ ), dan unit root test. Sedangkan order $\mathrm{p}$ dan $\mathrm{q}$ dapat ditentukan dengan beberapa kriteria, misalnya dengan meminimalkan Akaike information criterion (AIC), corrected AIC (AICc), dan Bayesian Information Criterion (BIC).

2) Estimasi Parameter: Setelah order ARIMA diidentifikasi, tahapan selanjutnya yaitu mengestimasi parameter autoregressive $\varphi_{1}, \varphi_{2}, \ldots$, $\varphi_{\mathrm{p}}$ dan moving average $\theta_{1}, \theta_{2}, \ldots, \theta_{\mathrm{q}}$. Estimasi dilakukan dengan menggunakan teknik optimasi baik linear maupun nonlinear seperti least square, maximum likelihood, dan metode optimasi lainnya untuk meminimalkan error. 
3) Pemeriksaan Diagnostik: Pemeriksaan diagnostik dilakukan untuk menguji apakah model yang dibangun layak untuk digunakan dalam peramalan. Pada tahapan ini metode pengujian yang umum dilakukan di antaranya dengan menggunakan uji Ljung-Box Q.

Untuk mengimplementasikan ARIMA dalam prediksi harga bahan pokok ini, maka penelitian ini dibagi menjadi lima tahap, yaitu: pengumpulan data, data preprocessing, implementasi ARIMA, pembuatan visualisasi interaktif hasil prediksi, serta pengukuran kinerja dan analisis. Alur tahapan ini dapat dilihat pada Gambar 2.



Gambar 2. Alur Tahapan Penelitian

\section{A. Pengumpulan Data}

Data historis harga bahan pokok nasional didapatkan dari Kementerian Perdagangan Republik Indonesia (Kementerian Perdagangan Republik Indonesia, 2017). Data tersebut terdiri dari harga harian beberapa komoditas mulai dari 1 September 2010. Dari data tersebut, data harga harian 12 bahan pokok mulai bulan Mei 2012 hingga Juli 2017 diambil untuk dijadikan sebagai target prediksi. Statistik mengenai data tersebut tersaji dalam Tabel 1.

\section{B. Data Preprocessing}

Data historis yang didapatkan dari Kementerian Perdagangan Republik Indonesia tersebut tidak mencakup semua data harian pada rentang waktu yang disebutkan di atas. Terdapat beberapa data harian yang hilang atau tidak tersedia (missing values). Dalam pembuatan dataset untuk prediksi harga bahan pokok ini, data yang hilang tersebut diestimasi dengan menggunakan interpolasi linear. Titik-titik data yang ada dihubungkan dengan garis lurus, sedangkan nilai yang ingin diketahui diperkirakan dengan mengambil nilai pada garis penghubung tersebut (Bradie, 2006). Proses interpolasi ini diilustrasikan pada Gambar 3.



Gambar 3. Gambaran interpolasi linear. Lingkaran merupakan titik data yang diketahui sedangkan persegi merupakan titik data baru yang dihasilkan dari proses interpolasi. Pengukuran Kinerja dan Analisis

Dari data tersebut, 365 nilai terakhir (1 tahun, mulai dari 1 Agustus 2016 hingga 31 Juli 2017) dari masing-masing komoditas kemudian disimpan sebagai test set yang akan digunakan untuk mengevaluasi performa model ARIMA, sedangkan sisanya digunakan sebagai training set untuk pembuatan model.

\section{Implementasi ARIMA}

Model ARIMA untuk memprediksi harga bahan pokok diimplementasikan dengan menggunakan fungsi auto.arima pada package forecast di bahasa pemrograman R. Fungsi tersebut mengembalikan model ARIMA dengan order $p, d$, dan $q$ terbaik yang ditentukan

TABEL 1. StATISTIK HARga 12 Bahan POKOK NASIONAL

\begin{tabular}{lrrrrr}
\hline \hline \multirow{2}{*}{ Komoditas } & \multicolumn{5}{c}{ Harga (Rp) } \\
\cline { 2 - 6 } & \multicolumn{1}{c}{ Rata-rata } & \multicolumn{1}{c}{ Min } & \multicolumn{1}{c}{ Max } & Std. Deviasi & Koef. Variasi \\
\hline bawang merah & $29,006.83$ & $11,892.00$ & $67,935.00$ & $10,153.04$ & 0.35 \\
beras medium & $9,499.08$ & $7,872.00$ & $29,009.00$ & $1,200.12$ & 0.13 \\
cabai merah biasa & $30,317.86$ & $17,568.00$ & $74,445.00$ & $8,584.99$ & 0.28 \\
cabai merah keriting & $30,729.42$ & $13,582.00$ & $74,351.00$ & $9,167.32$ & 0.30 \\
daging ayam broiler & $29,221.55$ & $23,706.00$ & $60,035.00$ & $2,712.18$ & 0.09 \\
daging sapi & $100,542.41$ & $73,255.00$ & $119,300.00$ & $12,273.47$ & 0.12 \\
gula pasir & $12,717.78$ & $11,078.00$ & $16,360.00$ & $1,197.34$ & 0.09 \\
kedelai impor & $10,465.13$ & $8,415.00$ & $12,200.00$ & 800.59 & 0.08 \\
kedelai lokal & $10,506.64$ & $1,845.00$ & $14,500.00$ & 694.36 & 0.07 \\
minyak goreng curah & $11,055.00$ & $9,900.00$ & $12,090.00$ & 593.69 & 0.05 \\
telur ayam ras & $20,863.00$ & $16,578.00$ & $41,317.00$ & $2,373.79$ & 0.11 \\
tepung terigu & $8,553.06$ & $7,549.00$ & $10,469.00$ & 498.95 & 0.06 \\
\hline \hline
\end{tabular}




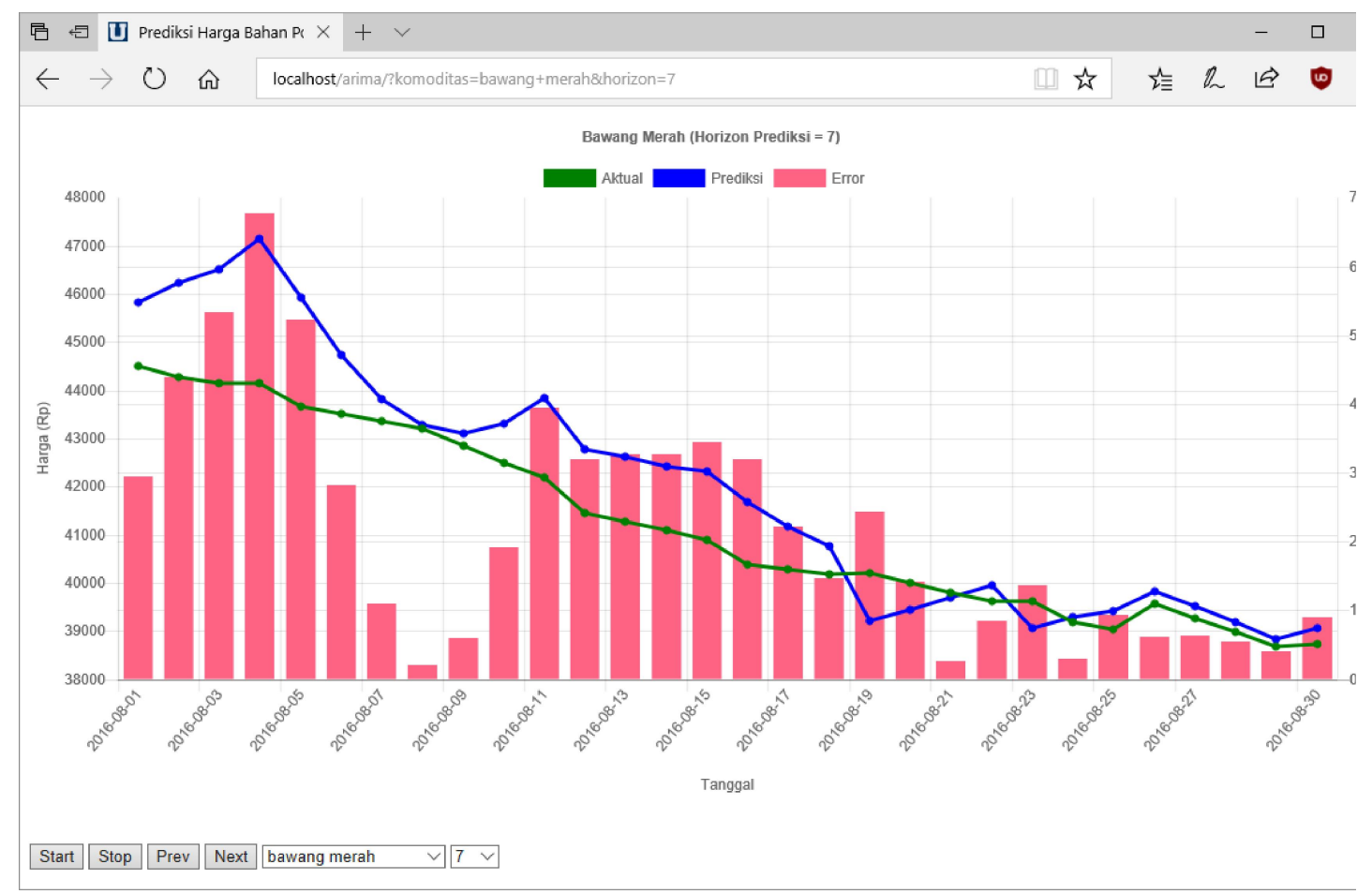

Gambar 4. Tampilan Visualisasi Hasil Prediksi

berdasarkan nilai AIC, AICc, atau BIC. Detail mengenai fungsi auto. arima dapat dilihat dalam studi (Hyndman \& Khandakar, 2008).

\section{Pembuatan Visualisasi Hasil Prediksi}

Hasil implementasi ARIMA selanjutnya divisualisasikan untuk mempermudah proses analisis. Visualisasi dibuat dengan menggunakan bahasa pemrograman PHP, HTML, dan Javascript. Tampilan visualisasi ini dapat dilihat pada Gambar 4.

\section{E. Pengukuran Kinerja dan Analisis}

Dalam prediksi harga bahan pokok ini, empat horizon prediksi akan diujikan: 1, 7, 15, dan 30 . Error akan dihitung pada masing-masing titik prediksi tersebut. Untuk mengevaluasi performa dari ARIMA, kami mengukur mean absolute percentage error (MAPE) yang ditunjukkan dalam persamaan (5). Disini, $x_{i}$ dan $\hat{x}_{i}$ berturut-turut melambangkan nilai aktual dan prediksi untuk observasi ke- $i$ dalam test set, sedangkan $n$ melambangkan banyaknya data di test set.

$$
\text { MAPE }=\frac{100 \%}{n} \sum_{i=1}^{n}\left|\frac{x_{i}-\hat{x}_{i}}{x_{i}}\right|
$$

\section{HASIL DAN PEMBAHASAN}

Tabel 2 menunjukkan performa ARIMA dalam memprediksi harga bahan pokok dalam beberapa horizon prediksi. Terlihat bahwa secara umum ARIMA dapat memprediksi harga bahan pokok dengan cukup akurat dengan rata-rata error untuk semua komoditas dan horizon menunjukkan nilai $2.22 \%$ (akurasi 97.78\%). Seiring dengan meningkatnya horizon prediksi, akurasi ARIMA cenderung menurun untuk semua komoditas. Penurunan tersebut tidak terlalu signifikan untuk sebagian besar komoditas, kecuali untuk bawang merah, cabai merah biasa, dan cabai merah keriting dimana error meningkat cukup besar dengan naiknya horizon prediksi. Hal ini berhubungan erat dengan statistik harga masing-masing bahan pokok yang ditunjukkan pada Tabel 1 dimana komoditas yang koefisien variasi harganya lebih besar cenderung lebih sukar untuk diprediksi dibanding harga komoditas lain dengan koefisien variasi yang lebih kecil.

Tabel 3 menunjukkan error maksimum untuk tiga komoditas dimana model ARIMA menunjukkan akurasi terendah. terlihat bahwa periode dengan error tertinggi terjadi pada rentang waktu yang hampir bersamaan. fluktuasi harga yang menyebabkan rendahnya akurasi prediksi untuk ketiga bahan pokok tersebut dapat dipengaruhi oleh momen puasa (bulan Ramadhan di penanggalan Hijriah) dan hari raya, baik Idul Fitri (bulan Syawal) maupun Idul Adha (bulan Dzulhijjah) di Indonesia. Permintaan untuk bahan pokok cenderung tinggi pada periode puasa dan hari raya yang belum tentu dapat diimbangi dengan pasokan yang ada (Setiawan \& Hadianto, 2015). Kenaikan harga akibat kelangkaan ini dan upaya pemerintah dalam melakukan operasi pasar untuk mengendalikan harga menyebabkan terjadinya 
TABel 2. PERforma ARIMA untuk PREDIKSI HaRga BAHAN POKOK

\begin{tabular}{lccccc}
\hline \multirow{2}{*}{ Komoditas } & \multicolumn{4}{c}{ Horizon Prediksi } & \multirow{2}{*}{ Rata-rata } \\
\cline { 2 - 5 } & $\mathbf{1}$ & $\mathbf{7}$ & $\mathbf{1 5}$ & $\mathbf{3 0}$ & \\
\hline bawang merah & $0.71 \%$ & $3.18 \%$ & $6.03 \%$ & $9.74 \%$ & $4.92 \%$ \\
beras medium & $0.15 \%$ & $0.35 \%$ & $0.40 \%$ & $0.51 \%$ & $0.35 \%$ \\
cabai merah biasa & $1.08 \%$ & $4.80 \%$ & $9.09 \%$ & $12.74 \%$ & $6.93 \%$ \\
cabai merah keriting & $0.99 \%$ & $4.63 \%$ & $8.40 \%$ & $12.20 \%$ & $6.55 \%$ \\
daging ayam broiler & $0.71 \%$ & $1.72 \%$ & $2.71 \%$ & $3.74 \%$ & $2.22 \%$ \\
daging sapi & $0.11 \%$ & $0.31 \%$ & $0.46 \%$ & $0.59 \%$ & $0.37 \%$ \\
gula pasir & $0.27 \%$ & $0.55 \%$ & $0.91 \%$ & $1.86 \%$ & $0.90 \%$ \\
kedelai impor & $0.15 \%$ & $0.30 \%$ & $0.41 \%$ & $0.51 \%$ & $0.34 \%$ \\
kedelai lokal & $0.39 \%$ & $0.91 \%$ & $1.15 \%$ & $1.44 \%$ & $0.97 \%$ \\
minyak goreng curah & $0.13 \%$ & $0.46 \%$ & $0.93 \%$ & $1.92 \%$ & $0.86 \%$ \\
telur ayam ras & $0.58 \%$ & $1.27 \%$ & $2.00 \%$ & $3.07 \%$ & $1.73 \%$ \\
tepung terigu & $0.28 \%$ & $0.53 \%$ & $0.63 \%$ & $0.76 \%$ & $0.55 \%$ \\
\hline Rata-rata & $0.46 \%$ & $1.58 \%$ & $2.76 \%$ & $4.09 \%$ & $2.22 \%$ \\
\hline \hline
\end{tabular}

TABel 3. ERror MaKsimum untuK Tiga Komoditas DENGAN AKURASi TERENDAH

\begin{tabular}{lcccc}
\hline \hline Komoditas & Horizon & Error Maks. & Tanggal & Tanggal (Hijriah) \\
\hline \multirow{3}{*}{ bawang merah } & 1 & $31.06 \%$ & $30-05-2017$ & 4 Ramadhan 1438 \\
& 7 & $65.35 \%$ & $05-06-2017$ & 10 Ramadhan 1438 \\
& 15 & $82.79 \%$ & $13-06-2017$ & 18 Ramadhan 1438 \\
& 30 & $74.57 \%$ & $28-06-2017$ & 4 Syawal 1438 \\
cabai merah biasa & 1 & $6.97 \%$ & $21-06-2017$ & 26 Ramadhan 1438 \\
& 7 & $27.82 \%$ & $29-06-2017$ & 5 Syawal 1438 \\
& 15 & $53.22 \%$ & $07-07-2017$ & 13 Syawal 1438 \\
& 30 & $46.79 \%$ & $22-07-2017$ & 28 Syawal 1438 \\
cabai merah keriting & 1 & $5.37 \%$ & $28-09-2016$ & 27 Dzulhijjah 1437 \\
& 7 & $22.78 \%$ & $21-09-2016$ & 20 Dzulhijjah 1437 \\
& 15 & $39.01 \%$ & $24-09-2016$ & 23 Dzulhijjah 1437 \\
\hline \hline
\end{tabular}

fluktuasi harga yang cenderung susah untuk diprediksi. Eksperimen lebih lanjut diperlukan dalam hal ini.

\section{KESIMPULAN}

ARIMA telah digunakan untuk memprediksi harga bahan pokok nasional dalam jangka pendek antara 1 hingga 30 hari ke depan. Eksperimen menunjukkan bahwa model ARIMA yang dibangun mampu memprediksi harga bahan pokok dengan cukup akurat dengan rata-rata error $2.22 \%$. Hasil yang didapatkan menunjukkan dengan meningkatnya horizon prediksi, penurunan akurasi dari sebagian besar bahan pokok yang diujikan cukup rendah.

Tiga bahan pokok yang menunjukkan penurunan akurasi dengan meningkatnya horizon prediksi adalah bawang merah, cabai merah biasa, dan cabai merah keriting. Fluktuasi harga ketiga komoditas tersebut berhubungan dengan periode puasa dan hari raya. Dalam penelitian berikutnya, akan dilakukan investigasi lebih lanjut mengenai pengaruh periode-periode tersebut terhadap prediksi dan mengikutsertakan periode atau waktu dalam model prediksi serta menggabungkan hasil dari model ARIMA dengan model-model prediksi lain seperti neural network untuk meningkatkan akurasi prediksi

\section{DAFTAR PUSTAKA}

Bradie, B. (2006). A friendly Introduction to Numerical Analysis. Pearson Prentice Hall.

Ditakristy, M. L., Saepuddin, D., \& Nhita, F. (2016). Analisis dan Implementasi Radial Basis Function Neural Network dalam Prediksi Harga Komoditas Pertanian. E-Proceeding of Engineering , 3 (1), 1130-1139.

Ediger, V. Ş., \& Akar, S. (2007). ARIMA Forecasting of Primary Energy Demand by Fuel in Turkey. Energy Policy, 35 (3), 1701-1708.

Firdaus, M. (2012). Manajemen Agribisnis. Jakarta: Bumi Aksara.

Goyal, P., Chan, A. T., \& Jaiswal, N. (2006). Statistical Models for the Prediction of Respirable Suspended Particulate Matter in Urban Cities. Atmospheric Environment , 40 (11), 2068-2077.

Hikichi, S. E., Salgado, E. G., \& \& Beijo, L. A. (2017). Forecasting Number of ISO 14001 Certifications in the Americas using ARIMA Models. Journal of Cleaner Production , 147, 242-253.

Hyndman, R. J., \& Khandakar, Y. (2008). Automatic Time Series Forecasting: The Forecast Package for R. Journal of Statistical Software , 27 (3), 122. 
Kementerian Perdagangan Republik Indonesia. (2017). Tabel Harga Kebutuhan Pokok Nasional. Dipetik August 23, 2017, dari Kementerian Perdagangan Republik Indonesia: http://www.kemendag.go.id/id/economicprofile/prices/national-price-table

Liu, P.-W. G. (2009). Simulation of the Daily Average PM10 Concentrations at Ta-Liao with BoxJenkins Time Series Models and Multivariate Analysis. Atmospheric Environment , 43 (13), 2104-2113.

Mohamed, Z., \& Bodger, P. (2005). Forecasting Electricity Consumption in New Zealand using Economic and Demographic Variables. Energy, 30 (10), 1833-1843.

Nanggala, S., Saepuddin, D., \& Nhita, F. (2016). Analisis dan Implementasi Elman Recurrent Neural Network untuk Prediksi Harga Komoditas Pertanian. E-Proceeding of Engineering , 3 (1), 1253-1261.
Sen, P., Roy, M., \& Pal, P. (2016). Application of ARIMA for Forecasting Energy Consumption and GHG Emission: A Case Study of an Indian Pig Iron Manufacturing Organization. Energy, 116, 1031-1038.

Setiawan, A. F., \& Hadianto, A. (2015). Fluktuasi Harga Komoditas Pangan dan Dampaknya Terhadap Inflasi di Provinsi Banten. Skripsi, Institut Pertanian Bogor, Ekonomi.

Widyadarma, D. M., Saepuddin, D., \& Nhita, F. (2016). Prediksi Harga Komoditi Pertanian Menggunakan Algoritma Hybrid Jaringan Syaraf Tiruan Arsitektur Elman Dengan Algoritma Genetika. E-Proceeding of Engineering , 3 (1), 1263-1266. 